\title{
THE STUDIES ON THE OBJECTIVE OLFACTORY TEST BY GALVANIC SKIN RESPONSE (REFLEX)
}

\author{
By \\ HiDEYo ASAKA \\ From the Depertment of Oto-Rhino-Laryngology, Shöwa Univ. School of Medicine, \\ Tokyo Japan (Director: Prof. T. Yamamoto., M.D.)
}

Experiments were made in order to examine the possibility of objective olfactory test, applying galvanic skin reflex and conditioned galvanic skin reflex.

\section{Part I.}

Galvanic skin reflex by olfactory stimulus

1) The experiments were performed in 50 cases with normal in smell sense and in 20 cases by those with disosmia.

2) The following four smell substances were used as the olfactory stimuli; strawberry essence, tomato flavour, amylacetic acid, and walnut flavour.

3) Whether to give the previous instruction or not had a strong influence upon the reaction. The persons who were given the previous instruction showed the reaction in 7 cases out of 10 cases (70.0 $\%$ ) ; but those who had no instruction beforehand showed the reaction only in 2 cases out of 10 cases.

4) The adaption was easily developed, especially when the interval of time of stimulus became short, the frequency of response decreased. It was on the average 3.1 frequency in the interval of one minute, and 1.9 frequency in the interval of 20 seconds.

5) Various kind of experiments on olfactory stimulus were performed in 13 cases. The cases which did not utterly react were 3 cases out of 13 cases. The cases which did not react to some kinds of smell substances, that is, the cases of partial non-reaction were 4 cases out of 13 cases.

6) Relation to the order of olfactory stimulus with the frequent reaction and the difference of magnitude of reaction could not be observed.

7) In the comparison of the frequency of reaction by the pleasant smell (strawberry essence) and unpleasant smell (tomato flavour), the unplea. sant smell reacted slightly easier than the pleasant smell.

8) Other experiments by the various density of the substances were performed about 27 cases. Firstly distilled water was used and then straw. berry essence as comparison.

The latter solution was at first diluted 6400 times and gradually made into higher concentration up to the original solution.

The subjective threshold was showed in all cases by 6400 times-diluted solution. As compared with the above results, 5 cases reacted with the response threshold with 6400 times-diluted solution, 3 cases with 400 times-diluted solution, 2 cases with the 100 times-diluted solution, and 10 cases did not react.

9) Under the above results, the subjective threshold was tested in the cases of disosmia, in which 11 cases reacted out of 15 cases of hyposmia. The difference between the subjective threshold and the response threshold was slightly less than that of people normal in olfactory sense.

10) All the cases did not react in the cases of anosmia.

Part II.

Conditioned Galvanic Skin Reflex

1) Experiments on 45 normal persons and 20 cases of disosmia by means of PAVLOV Type Conditioned Reflex was carried out.

2) As the conditioned stimuli, strawberry essence, amylacetic acid, walnut flavour were used; and as unconditioned stimulus, electric shock stimulus was used.

3) At reinforcement tests, the combination of 
conditioned \& unconditioned stimulus and the unconditioned stimulus were used each by 50 per cent.

4) At the experiments of reinforcement and extinction, $73.3 \%$ of all the cases were presented conditioning, and at extinction tests $81.1 \%$ were extinct at 7 th to 10 th trial.

5) In the comparison of the percentage of reinforcement by several kinds of smell substance, no difference was observed among the strawberry essence as pleasant smell, walnut flavour as unpleasant smell, and amylacetic acid as stimulative smell.

6) Similar results were obtained both by reinforcement by diluted solution and reinforcement by the original solution.

7) At the tests of threshold of normal persons $72.7 \%$ agreed with the subjective threshold, and $27,3 \%$ reacted at the one grade higher density, which can be determined as the better results than obtained in Part I.
8) At the threshold tests by the cases of hyposmia, $73.3 \%$ of them showed reaction, and difference from the subjective threshold was nearly the same as of normal persons.

In this percentage, the four cases which showed no reaction in Part $I$ were contained, two of which showed reaction in this test.

9) None of the cases of marked hyposmia was reinforced.

10) According to the Objective Olfactory Test by means of Galvanic Skin Reflex, it was observed that the cases of non-reaction was minimized in the experiement as mentioned in the above Part II. as well as the experiement as mentioned in the above Part $\mathrm{I}$.

Either method as specified in the above Part I and Part II. should be applicable to the objective olfactory test, and furthermore, in the cases of non-reaction by Galvanic skin reflex method, conditioned galvanic skin reflex method should be additionally executed.

\title{
皮膚電気反射による他覚的嗅覚検查法の研究
}

\author{
第 1 編 嗅刺激に上る皮膚電気反射 \\ 第 2 編 条件皮膚電気反射
}

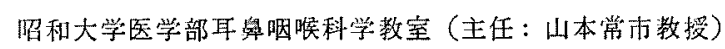

大学院学生 浅 賀 英 世

目次

\section{痛

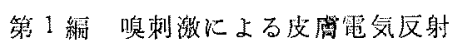

筙1章 緒㖣

第 2 幛 正常者

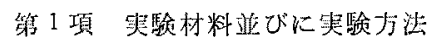

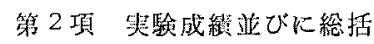

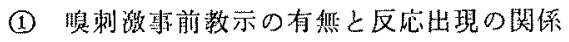

(2) 嗅制湤の反復による順応の状態

a) 刺激間隔時間の長短

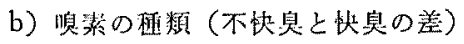

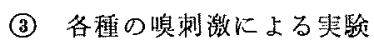

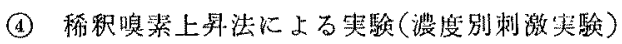
第3章 病的者

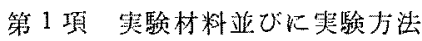

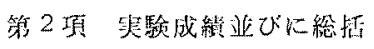

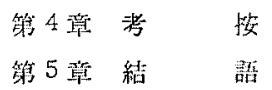

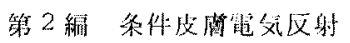

第1潮稀司

第2 章 正 常 者

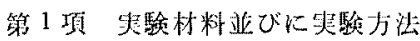


第 2 項 那験成績业びに総颃

(1) 流化の尖䮖

(2) 消去の矢䮖

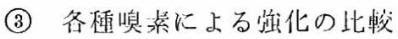

(4) 濃度: 别実駼（間值测分:

籁了章 焫 的者

第 1 工

第 2 項 実戨成紹业びに総括

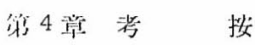

第 5 算 結 勘

序言

従来施行されている嗅覚検査法は専ら被検者の主推に 基く応答によつて測定される自覚的検査法である。-
方, 聴力の他覚的検査法に就いては現在迄に多数の報告 が見られるが，嗅覚に関するものは脳波を利用する方法 等が我々の報告も含めて 2 〜見られるのみであり，特 に条件反射を応用したものは外国文献にも全く見られな い.しかし，これ等は必ずしも真の意味の他覚的検査㳎 ではなく，むしろ非自覚的検査法と呼ぶのが適当である が, Goodhill 等は「現在本当の意味の他覚的方法と云 うものは殆んど存在しない」と云つているので一般にこ れら現行のものも他覚的検査法と呼んでいる.

私はこの広義の他覚的嗅覚検査法を創製するために嗅 刺数の無条件反射に属するものとして GSR 法, 条件反 射を利用したものとして Pavlov 型条件反射の実験を行 つたので報告する．

第了編 嗅刺激による皮膚電気反射

第 1 章 緒言

皮膚の 2 力所につけた電極間に微小電㳘を流すときの 抵抗が種々の刺激, 即ち感覚的あるいは感情的な刺激に より一版的に变化する現象を1888 年 Féré が発見した。 又, 同様な刺激によつて皮膚上の 2 電極間に電位の変化 の起る事を1890年 Tarchanoff が見出した。これ等の 現象は Galvanic skin response or reffex (GSR) 即ら 皮简電気反応とか Psychogalvanic skin resistance (response) 略して PGSR と云ら名称が附され，今日 広く各方面に応用されている。例えば臨床面においても 末梢交感神経機能検査，痛覚，睡眠，自律神経系緊張 度，条件反射の研究等が挙げられるが特に吾科領域に括 いては聴力の 他覚的検査への応用の面で研究されてい る.

偖，我々は先に嗅刺激による脳波の諸反応の観察か ら嗅覚の他覚的検查法に関する研究を発表しているがこ こでは皮腐電気反応を応用した他覚的嗅覚検査法の可能 性を検討するため正常者並びに病的者についての実験を 行つたのでその成績を報告する．

\section{第 2 章 正常 者}

第 1 項 䇛験材料並びに奏験方法

被检者：鼾腔, 副鼻腔に異常を認めず嗅覚障害を訴え ないもので嗅覚の 稀釈試韭成績が正常値即ち $8 \pm 1$ ( ス トロベリー原液の 6400 倍溶液）を呈した成人 50 例を用 いた.

装置：(1) 通電法：測定回路として第 1 図 (写真) 第

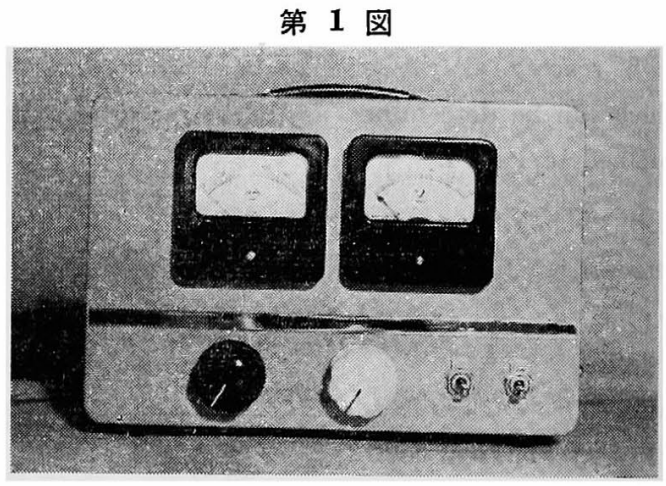

第 2 図

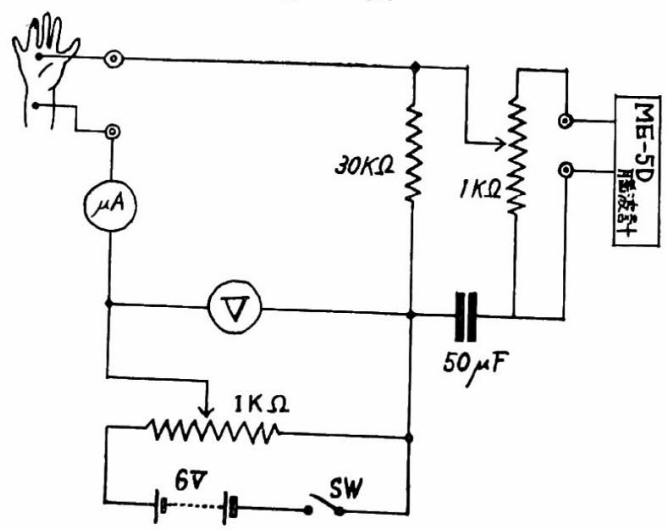

2 図の如き単純回路を作成し抵抗測定のための通電電流 は 30〜80 $\mu \mathrm{A}$ となるように增減した。増幅器並びに記 
跳器としては日本光㫼製 ME-5D 型脳波計を使用し皮

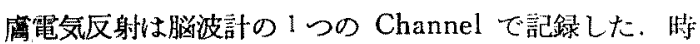
定数は 4 秒 (Low Cut 1) で $1 \mathrm{mv}$ に刘しPen writing の振れが $5 \mathrm{~mm}$ であるように調整し 記録紙の進行速度 を $1 \mathrm{~cm} / \mathrm{sec}$ とした。誘導電極は直径 $1 \mathrm{~cm}$ の銀板霄極 2 個を用い，1 個を手掌に，他の 1 個を前腕手掌側の手 関節附近に夫々飽和食塩水を浸した綿花を敷いた上から ゴムパンドで密着固定した。

(2) 電位法: 日本光電製 ME-5D 型脳波計を使用し, この1つの channel で記録した. 時定数は 4 秒 (Low Cut 1) で $1 \mathrm{mv}$ に対してPenの振独 $10 \mathrm{~cm}$ になる ように調節した。.

実験方法: 脳波検査室に被榆者を入れ小卓子に雨手を 置かせ電極等圈後, 閉眼させて 5 分間安静を保たせてか ら，そのままの状態で実験を開始した。即ち嗅刺激とし て各種の嗅素（ストロペリーエッセンス，トマトソース フレーバー, ウオルナットフレーバー, 醋酸アルミ) 並 びに対照として蒸溜水を綿棒に浸して鼻孔直下約 $1 \mathrm{~cm}$ のところに吸気時に一致させて差し出した，更に別に音 刺激をC 音文を用いて与えた。搝素の濃度別刺激実駼 はストロペリーエッセンスによる稀勫試駼用の嗅素系列 （6400倍，1600 倍，400 倍，100倍，25 倍，原液）を用 い, 順序は低濃度のものから始めて上茩法に彷つた。刺 激時間は 3 秒, 間隔は 1 分（但し順応の実騟では20 秒 と1分) とした。

なお，室温は $18^{\circ} \mathrm{C} \sim 25^{\circ} \mathrm{C}$ を保つようにした。

第 2 項 実験成績並びに総括

実歌に際して手掌電梗が陰性の時に記録紙上で上向き のカーブを描くようにしたが，刺激を与克てから1〜3 秒後に上向きの単相性乃至 $2 \sim 3$ 相性の波形が 記録され た場合これを反応曲線と見，陽性（十）とした．即ち反 応曲線は第 3 図に 1 例を示した通りである。このような 曲線が画した場合を（十）とし，全く動摇の認められな い場合を（一）として成績を表示したなお，舁駼心大

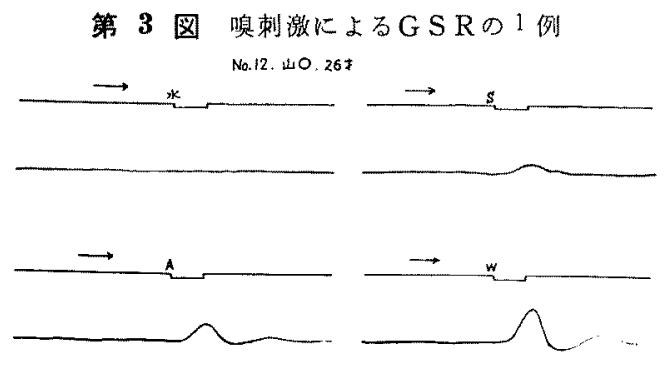

部分通笔泣に占つた。

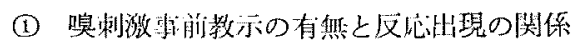

ストロベリーエッセンス原液の嗅制激を子小包いに注 意するよらにとの事前教示を与えた場合と全く無警告で 行つた場们とを同一の10例について实験した，その成 續恃第 1 表に示与通り然警告の場合では10 例中 2 例 （20\%）に（ナ）が得られたが其前教示を行なつた場合 では10例中7例（70\%）に（十）が得られた。な祘， 以下の备䒠駖に执いては轿前教示を行つた。

第 1 表

\begin{tabular}{|c|c|c|c|c|}
\hline & & & 反 底 出 & 現 \% \\
\hline 俱 & 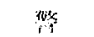 & 告 & 10 例宋 2 侧 & $(20 \%)$ \\
\hline & 䔕 散 & $\bar{\pi}$ & 10例我 7 例 & $(70 \%)$ \\
\hline
\end{tabular}

(2) 嗅刺激の反復に上る順応の状態

刺激を繰り返觉し与えると反応が減抲乃至消失するが この順応について次の 2 要因別に夷験した。

a) 刺激間隔時間の長短

ストロベリ一嗅刺激を刺激時間 3 秒で閒隔 20 秒とし た場合と閒隔 1 分とした場合の夫々について反応が連続 して生ずる回数を求めた，その成績は第 4 図と第 5 图化 示寸通りで，閒隔 20 秒の場合は 10 例中反応出現が 2 回 迄のものが 8 例で殆んど大半を占めたが問隔 1 分の場合

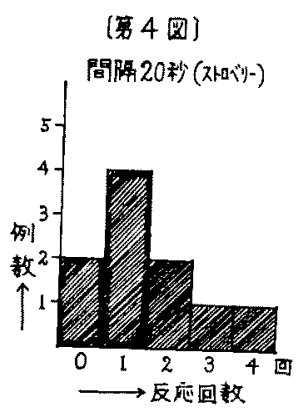

(第5圆)

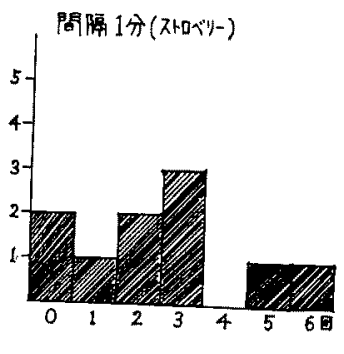

(第6圆)

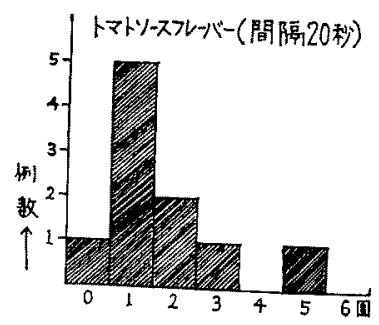


は区応回数の多いものの例数が增加している. 平均回数 は闹者加1.9国, 後者が3.1回となる。

b) 喚素の種類（不快臭と快臬の盖）

前記 10 例火快臭としてストロベリーエッセンス，不

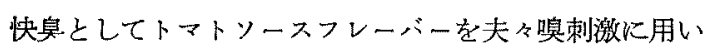

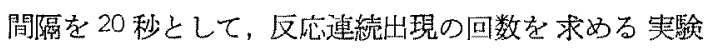
を施行した成續ではトマトソースフレーバーの場合も第 6 四の如くとなり, 平均回数も1.9回で先のストロベリ ーエッセンスの成續（第 4 図）とほぼ類似していた。

\section{(3) 各種の鮕刺激に上る実験}

4 種の舆素原液を用い13 例に就て 施行した、なお。,

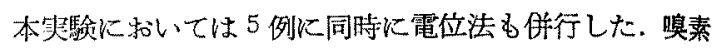
の刺激順序は一定にせず各例で異るものるある. 成績は 第 2 表の通りで，13 例中全く無反応であつたものが3例 見られ，嗅素の種類によつてある種類に反応の出現しな かつた例，即ち部分的無反応例が 4 例あつたが反応出現 の有無及び反忘の大きさの差は刺激の順序之関係を諗め ずたボトマトソースやウオルナットの如き不快臭乃至

第 2 表 各種の鮕紫原液によるGSR

\begin{tabular}{|c|c|c|c|c|c|c|c|c|c|c|c|c|c|c|c|c|}
\hline 症 & \multirow{2}{*}{ 氏 } & \multirow{2}{*}{ 名 } & 年 & \multicolumn{2}{|c|}{ 嗅 } & \multicolumn{2}{|l|}{ 刺 } & 激 & \multirow{2}{*}{$\begin{array}{l}\text { 音 } \\
\text { 刺 } \\
\text { 激 }\end{array}$} & \multirow{2}{*}{$\begin{array}{l}\text { 判 } \\
\text { 定 }\end{array}$} & \multirow{7}{*}{\multicolumn{6}{|c|}{ 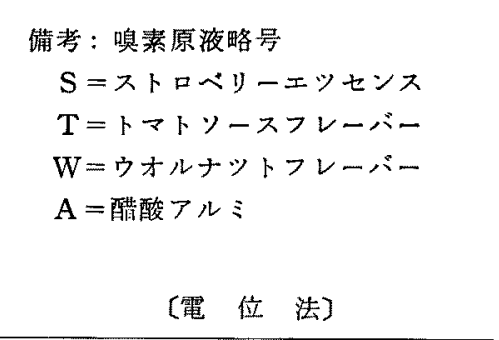 }} \\
\hline 例 & & & 令 & 1 & 2 & 3 & 4 & 5 & & & & & & & & \\
\hline 1 & 守 & 0 & 23 & $S+$ & $T+$ & 水一 & $\mathrm{A}+$ & W+ & + & + & & & & & & \\
\hline 2 & 浅 & 0 & 20 & SH & SH & $\mathrm{AH}$ & 水一 & & $H$ & + & & & & & & \\
\hline 3 & 山 & 0 & 25 & $S+$ & 水一 & $\mathrm{AH}$ & $\mathrm{T}+$ & $w+$ & $H$ & + & & & & & & \\
\hline 4 & 湯 & 0 & 25 & 水一 & $s-$ & $T-$ & $A-$ & W- & - & - & & & & & & \\
\hline 5 & щ & 0 & 25 & $S+$ & 水一 & $A+$ & $T-$ & $w-$ & - & \pm & & & & & & \\
\hline 6 & 山 & 0 & 24 & $s+$ & 水一 & $A+$ & $T-$ & $W-$ & + & \pm & 唲 & & 刺 & & 澈 & 音 \\
\hline $\begin{array}{l}7 \\
8\end{array}$ & $\begin{array}{l}\text { 平 } \\
\text { 児 }\end{array}$ & $\begin{array}{l}0 \\
0\end{array}$ & $\begin{array}{l}27 \\
25\end{array}$ & $\begin{array}{l}\text { AH } \\
\text { SH }\end{array}$ & $\begin{array}{l}S H \\
\text { 水 }-\end{array}$ & $\begin{array}{l}\text { 水一 } \\
\mathrm{AH}\end{array}$ & $\begin{array}{l}\mathrm{W}+ \\
\mathrm{T}-\end{array}$ & $\begin{array}{c}\text { TH } \\
\mathrm{W}+\end{array}$ & $\begin{array}{l}H \\
H\end{array}$ & $\begin{array}{l}+ \\
+\end{array}$ & 1 & 2 & 3 & 4 & 5 & 测 \\
\hline 9 & 高 & 0 & 23 & $S-$ & $A-$ & 水一 & $T+$ & $w+$ & + & \pm & $S-$ & $A-$ & 水一 & TH & WH & $H$ \\
\hline 10 & 福 & 0 & 26 & $S+$ & 水一 & $A+$ & $\mathrm{TH}$ & WH & $H$ & + & $s+$ & 水一 & AHt & $\mathrm{TH}$ & WH & $H$ \\
\hline 11 & 森 & 0 & 29 & $s-$ & $\mathrm{T}-$ & 水一 & W- & $A-$ & - & - & $S-$ & $T-$ & 水一 & $W-$ & $A-$ & - \\
\hline 12 & 111 & 0 & 26 & $s+$ & 水一 & $A+$ & $\mathrm{TH}$ & WH & H & + & $s+$ & 水一 & $\mathrm{A}+$ & $\mathrm{TH}$ & WH & $H$ \\
\hline 13 & 森 & 0 & 28 & 水一 & $S-$ & W- & $\mathrm{T}-$ & $A-$ & - & - & 水一 & $S-$ & W- & $T-$ & $A-$ & - \\
\hline
\end{tabular}

悪臭とされているものにやや反応の出現をきたし易い傾 向があるかの上らに思われた. 勿論，無臭である水の場 合には全例共無反応であつた，通電法と電位法之の成績 の比較では両者ほぼ一致し特別の所見は得られなから た.

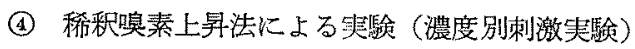

27 例に就て施行した，方法は通電法によつた。先ず 対照としての蒸溜水を用い続いてストロベリーエッセン スの 6400 倍溶液から順次高濃度に変之原液迄至つた。

自覚閵值は全例 6400 倍であるので反応闌值を表示する と第了表の通りである．なお，無反応例の10 例は除外 してある.表から明らかな如く反応閾值が自覚閶值, 即 ち 6400 倍と一致したものは 5 例 $(29.4 \%) ， 1600$ 倍のも のは 7 例 (41.2\%)，400倍のものは3 例 $(17.6 \%), 100$ 倍のものは2 例 (11.8\%) であつた。亳駼は全例に高濃 度の噮刺激負荷を行なつたがある濃度で反応が認められ
第 3 表 濃度別嗅刺激

\begin{tabular}{|c|c|c|c|c|}
\hline 症例 & 氏 & 名 & 年令 & G S R 䦵値 \\
\hline $\begin{array}{l}14 \\
15 \\
16\end{array}$ & $\begin{array}{l}\text { 藤 } \\
\text { 䕐 } \\
\text { 薄 }\end{array}$ & $\begin{array}{l}\bigcirc \\
0\end{array}$ & $\begin{array}{l}24 \\
25 \\
24\end{array}$ & $\begin{array}{l}6400 \times \\
1600 \times \\
1600 x\end{array}$ \\
\hline $\begin{array}{l}17 \\
18 \\
19\end{array}$ & $\begin{array}{l}\text { 名 } \\
\text { 舟 } \\
\equiv\end{array}$ & $\begin{array}{l}4 \\
0\end{array}$ & $\begin{array}{l}24 \\
25 \\
25\end{array}$ & $\begin{array}{r}1600 \times \\
400 \times \\
1600 \times\end{array}$ \\
\hline $\begin{array}{l}20 \\
21 \\
22\end{array}$ & $\begin{array}{l}\text { 北 } \\
\text { 堌 } \\
\text { 前 }\end{array}$ & $\begin{array}{l}\bigcirc \\
\bigcirc\end{array}$ & $\begin{array}{l}26 \\
24 \\
23\end{array}$ & $\begin{array}{l}6400 x \\
6400 x \\
6400 x\end{array}$ \\
\hline $\begin{array}{l}23 \\
24 \\
25\end{array}$ & $\begin{array}{l}\text { 今 } \\
\text { 阿 }\end{array}$ & $\bigcirc$ & $\begin{array}{l}25 \\
24 \\
30\end{array}$ & $\begin{array}{r}1600 x \\
400 x \\
1600 x\end{array}$ \\
\hline $\begin{array}{l}27 \\
32 \\
34\end{array}$ & $\begin{array}{l}\text { 市 } \\
\text { 及 } \\
\text { 岡 }\end{array}$ & $\begin{array}{l}\bigcirc \\
\bigcirc\end{array}$ & $\begin{array}{l}25 \\
25 \\
26\end{array}$ & $\begin{array}{r}6400 \times \\
100 \times \\
400 x\end{array}$ \\
\hline $\begin{array}{l}38 \\
40\end{array}$ & $\begin{array}{l}\text { 木 } \\
\text { 能 }\end{array}$ & 8 & $\begin{array}{l}29 \\
25\end{array}$ & $\begin{array}{r}1600 x \\
100 \times\end{array}$ \\
\hline
\end{tabular}


てもそれ以上のある高濃度で反応の起らない例があり， 又, 反応の大ささも必ずしも港度の濃さに並行してはい なかつた。

\section{第 3 章 病 的 者}

第 1 項 实験材料並び実験方法

被檢者：嗅党障害を主訴として当科に来院し稀釈試験 で愪覚減退を認められた者 15 例，並びに脱失と診断さ れたもの5 例に就いて実験を行つた，実験方法は第 2 章, 第 2 項 (4) の実験と全く同じ方法によつた.

\section{第 2 項 実験成績並びに総括}

実験成績は第 4 表に示す通りで無反応であつたるの4 例 $(26.7 \%)$ で前述の正常者群上り多少ではあるが反応 の得られた例が高率となつている，又，反応を示した11 例に批る自覚閶値との差が0，即ち一致したもの 4 例 (36.4\%)，自覚間值上り 1 段階高濃度で反応の 認められ たもの 5 例 $(45.4 \%) ， 2$ 段階高濃度で反応の認められた もの 2 例 $(18.2 \%)$ で，それ以上の差となつたものは1 例当無からた。

\section{第 4 表}

\begin{tabular}{|c|c|c|c|c|c|c|}
\hline 症例 & 氏 & 名 & 年令 & 自覚閵値 & G S R 闘値 & $\begin{array}{l}\text { 自覚間值 } \\
\text { と }\end{array}$ \\
\hline 1 & 小 & 0 & 34 & 1600 & 1600 & 一 致 \\
\hline 2 & 村 & 0 & 25 & 1600 & 1600 & 一 致 \\
\hline 3 & 高 & 0 & 21 & 100 & - & \\
\hline 4 & 道 & 0 & 24 & 400 & 100 & 1 段階 \\
\hline 5 & 金 & 0 & 24 & 25 & 1 & 1 段階 \\
\hline 6 & 大 & 0 & 30 & 400 & 25 & 2 段階 \\
\hline 7 & 太 & 0 & 29 & 100 & 25 & 1 段階 \\
\hline 8 & 加 & $\mathrm{O}$ & 54 & 100 & 100 & 一 致 \\
\hline 9 & 非 & 0 & 20 & 100 & - & \\
\hline 10 & 一 & 0 & 19 & 400 & 400 & 一 致 \\
\hline 11 & 0 & 生 & 31 & 100 & 25 & 1 段階 \\
\hline 12 & 上 & 0 & 25 & 1600 & - & \\
\hline 13 & 秋 & 0 & 27 & 100 & 1 & 2 段階 \\
\hline 14 & 山 & $\mathrm{O}$ & 19 & 400 & 100 & 1 段階 \\
\hline 15 & 吉 & 0 & 36 & 25 & - & \\
\hline
\end{tabular}

第 5 表

\begin{tabular}{|c|c|c|}
\hline 自覚闒值との差 & 正常 者 & 病的者 \\
\hline 一致したもの & $29.4 \%$ & $36.4 \%$ \\
\hline 自覚闓值より1段階高濃度 & $41.2 \%$ & $45.4 \%$ \\
\hline 白覚閥值より 2 段階高浱度: & $17.6 \%$ & $18.2 \%$ \\
\hline 自覚閾值より3段階高浸湿: & $11.8 \%$ & $0 \%$ \\
\hline
\end{tabular}

これと正常者群とを比較すると第 5 表の通りで，病的 者群の方がわずかではあるが自覚源值と一致した者の例 数が多く見られ，又，自覚閶値との差においても正常者 では3 段階高濃度で反応を認めた者があつたのに対し病 的者ではその差が 2 段階以内に全部入っていた，脱失例 においては全例無反応であった。

\section{第4章考按}

種々の刺激即ち感覚的乃至は感情的な刺激に応じて人 の皮膚電気抵抗が变化する現象即ち皮藏電気反射は未だ この作用の本態が全く解明されたとは云えないが大脳皮 質前運動領及び視床下部に反射中枢を置き交感神経を遠 心路とし, 汗腺を反応器官とする自律神経性反射である とされ交感神経が與鹪して汗腺の腺細胞形質の分極性の 低下が起り皮有電気抵抗が減少するのを観察するるので あると云われている。この現象を利用して耳科領域では 音響刺激に上る反応の実験と他賞的聴力検查の試みが従 来から幾つか報告されている。しかしながら他覚的検查 法として用いるには無反応者が比較的多いこと，順応を きたし易いこと等の難点が存する事で制約を受けるとさ れている．今回，私は先に述べた通り嗅刺激による皮苚 電気反応を実験し 他賞的嗅覚検查法えの応用を検討し た．先ず皮腐電気反応に批いて被倹者の心理的影響が大 きい之云う事実の有無者嗅刺激事前教示の有無と反応出 現の関係仙よつて実験した結果は既述の通りで事前教示 を行なつた場合に遥かに反応が現れ易くなつている。 又，正常者上り病的者の方が無反応例が少なからた事， 及び自党閥值々一致した者の例数が多い，換言すれば一 致率が高からた事，即ち正常者より嗅覚障害を主訴とし て来院した病的者の方が全体に反応が現れ易かつたと云 う事も結局被検者の心理的影響が大きいと云う事契によ るものと見るべきであるう．

本反応に打いて重要な一つの性質とされている順応に 就て嗅刺激に関してはいかなる様相を呈するかの实験を 行つた結果は刺激間隔時間が 20 秒と 1 分とでは連続反 応回数が前者で平均 1.9 回，後者で平均 3.1 回で間隔時 間が長い方が順応をきたし増い事が判り嗅素の種類別で は順応状態に差を認めなかつた。

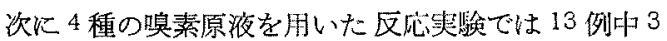
例 $(23 \%)$ の然反応者があり, 部分的然反応都即ちある 種の嗅素では反応の出現しなかつたるの4 例を加えると 7 例 $(54 \%)$ のものは検査に適さなからた霜になる。嗅 素の種類㸮では制激の順序上沁出現の有然及び大きさ との間に関連を認めず，唯トマトソースフレーバーやウ 
オルナット即ら不快臭乃至恶臭を発する嗅素の場合にや や反応が出現し易い傾向が想められた。これ怯不快臭仃 至恵臭の方が，より感情的な刺激を与えるためと思末 れ，これが反応に心理的な影響を与えるためであるうと 推考する。な括，先炕述べた順応関しては鈴木(篤郎) に上る音刺激の場合上比較し，嗅刺激の場合の方か顸応 をきたし昮いよらであるが，又，共間隔時間が大きな 要因となつている一方, 刺激の質の種類（音では純音, 1000 cps と牛の鳴声）も音の場合には大きな要因となつ

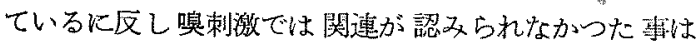
一見不可解な成續であるが，こ机等怯本来，教室の小烃 の報告による通り嗅覚々のものが非常に疲学（䐓応）を きたし易い感党であるためにこの順応が GSR の順応上 りも大きく作用する結果と思考する，濃度別刺激実駼で は自覚閔值と反応閾值との関連を調べたがその成績は前 述の通りであって，自覚閥值と一致したものは $29.4 \%$, 1 段階高濃度の清度番号 6 (1600 倍) であつたもの 41.2 \%を合計すると約 70\% 強となり，かなりよく自賞䜿值 と反応閾值が接近している。この成績は前記，鈴木の恥 力検査のための実駼成績「雨間值差 $\pm 10 \mathrm{db}$ 以内のもの 92.1\%」K比しやや少るが相当の一致度を示すもので一 応他覚的喚覚閾值检查に応用でさる上5に見光る。但し

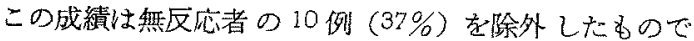
あるので総数に対しては約 44\%である事を考慮せ称ば ならない、な拉，ある潧度で反応が認められてもそれ以 上のある高濃度で反応の起らない例があつた事は既述の 通り順応が生じ易い事が一つの原因上考光られる。

刺激の強さ（濯度）と反応の大きさとの関係沉ついて は Bijeel, J. \& Van Iterson, は刺激の強さに比例した 皮庵電気反射が現れていると述べているが，私の实験で は原夜〜6400 倍間の強さの差においては特にそのよう な傾向は見られず，又，これを定量的に正確に測定する
には非分極電極等を使用せねばならないが今回の実験で は特に必要ではなかつたので施行しなかつた。

以上総括すると GSR にはその本態上相当の心理的関 与があるため反応発現には個体差，刺激としての嗔素の

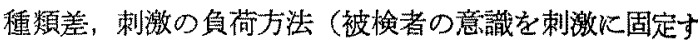
る事）等を考虑する必要がある事及び順応をきたし易い 点かから，刺激間隔を充分にとり弱刺激から強刺激炕变 換する方法，即ち上舁法を採用 せ小ばならない事等を GSR を疬用する上に不可欠の注意事項として挙げた いなお，これ等の注意事項に忠実であつても，電極間 抵抗の過大な場合，基線の動摇の激しい場合，全く反店 しない煬合等で不適当な者が相当数存するという障塞か゚ あり，これが GSR を指標とする嗅覚闒值検査の限界 となつているものである。

\section{第5 章 結語}

(1) 哭覚正常者 50 例，病的者 20 例に就て㒉刺激によ る皮痛電気反応の奏験を行なつた。

(2) 嗅刺激沉ついての事前教示の有無が反応出現に大 きな影響を示した，又正常者より病的者の方が反応が現 れ易からた。

(3) 順応が起り易く特に刺激間隔時間が短いと反応出 現回数が減少する。

(4) 悬刺激の種類別实験では $23 \%$ の無反応者があつた が，不快臭の方にやや反応出現をきたし易い傾向を認め た.

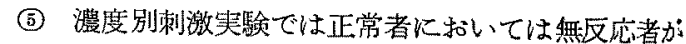
$37 \%$ 存在したが，病的者では $27 \%$ ，又自覚䦪値と他覚 間值上の差は前者では70\%において一致乃至近似した のに対し，後者は $82 \%$ に拝いて一致乃至近似ほぼ同し 結果を得た。

(6) 他觉的嗅覚恰查には上記各項を考慮して施行せ权 ばならない。

\section{第 2 編 条件皮䖉電気反射}

\section{第 1 章 楮 言}

Pavlov 型条件反射を利用した他覚的検查法は 1948年 Bordley, Hardy, Richter が䉓気ショックによる皮凮 電気反応を無条件反応とする研究を発表以来，多くの人 々に取上げられてきた。しかしそのいずれもが恥覚の他

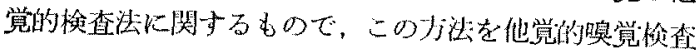
法に応用したものは全く鮰く，嗅覚に関してはわずかル
新美によつて嗅刺激による条件反射の可能性に付いての 硎究報告がなされているのみである。

私は籍1 編に执いてて皮膚電気反射を利用した他覚的㖵 賞娭查法汇就いて述べたが $37 \%$ に無反応例が見られ，

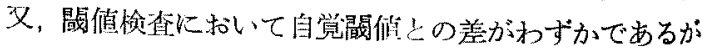

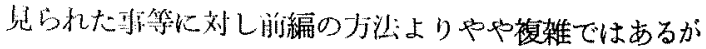
できらるかきり测定不能例を少なくする事を期待して本 
法を試みた所一応見るべき結果を得たので報告する，

\section{第 2 章 正 常 者}

第 1 項 実鉷材料並びに実験方法

被検者：睯副畀腔に異常を認めず嗅賞障害を訴えない

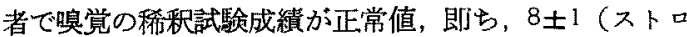
ベリ一原液の 6400 倍溶液)を呈した成人の中，しかる 嗅刺激が無条件刺激之なつて皮筬電気反射の起る例は除 外し，又，第 1 編第 2 章の実験で無反応となつた者も本 実験に使用した，合計 45 例である。

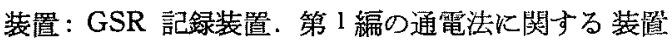
をそのます使用した。

電気刺澈発生蓄置. 第7 図の如き $8 \mu \mathrm{F}$ コンデンサー 放電法よる直流刺激をを用い，電源は90V 積層乾電池 と乙可変抵抗器により電压を贸化させ刺激の強さを調節 した.ショック電極は GSR 記録用と同様のものをGSR 測定之反刘側の手掌及び前腕手掌側の手関節附近に夫々 飽和食塩水を浸した䋨花を敷いた上からゴムバンドで密 着固定した。

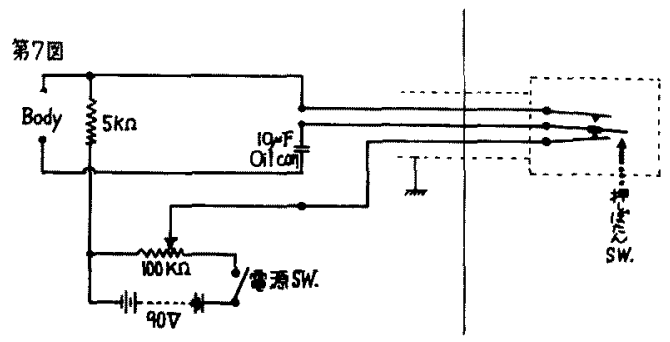

实験方法：第 1 編と同しく脳波検查室を使用，室温は $18^{\circ} \mathrm{C} \sim 25^{\circ} \mathrm{C}$ に保つようにし，被検者には目かくしを し，電極装着後，5分間の安静を保たせた後，実験を開 始した。

検者の 1 人が嗅素を浸した綿棒を呼吸に一致させて鼻 孔直下約 $1 \mathrm{~cm}$ の所にさし出す作業並び汇電気刺激用の 押ボタンを押した。

強化方法は第6 表に示す通りで50\% 部分強化とし16 回をるつて条件形成の様相を観察した. 16 回の施行に よっても条件形成できなかつたものに対しては最初にも ぞってもう16回強化を行った，32回の施行にても条件 形成できなかつたものは不能例とした。

第6 表中，間隔時間は 25〜40 sec の間で at random に選び $\mathrm{G}+\mathrm{S}$ (咱刺激+電気ショック) と $\mathrm{G}$ 嗅刺激だ け）の順序は不闰にしてある。

条件刺激としては強化及び消去の舆験ではストロベリ
第 6 表

\begin{tabular}{|c|c|c|c|c|c|c|}
\hline \multicolumn{2}{|c|}{ No. 間隔(秒) } & 刺 & 激 & No. & 間隔(秒) & 刺 激 \\
\hline 1 & - & G & $+\mathrm{S}$ & 9 & 35 & $G+S$ \\
\hline 2 & 40 & & F & 10 & 30 & G \\
\hline 3 & 30 & G & $+S$ & 11 & 25 & $G+S$ \\
\hline 4 & 35 & & $+s$ & 12 & 35 & $G+S$ \\
\hline 5 & 25 & & $\xi$ & 13 & 25 & G \\
\hline 6 & 30 & & $\xi$ & 14 & 25 & G \\
\hline 7 & 40 & & $+S$ & 15 & 30 & $G+S$ \\
\hline 8 & 25 & & $G$ & 16 & $\begin{array}{l}25 \\
35\end{array}$ & G \\
\hline
\end{tabular}

一原液を使用し，各種唤刺激による強化の比較実験では 快卓としてストロベリー原液, 不快卓としてウオールナ ットフレーバー原液，刺激臭として酷酸アルミを使用し た、稀釈喚素による強化実験並びに關值測定実験ではス トロベリ一原液の倍数稀釈系列より6番，4番すなわち 1600 倍，400 倍を使用した。

無条件刺激である電気ショックは条件刺激が与えられ てから $0.5 \mathrm{sec}$ 遅れて与えられるのが最適であるが，啅 荸が唤粘膜に達する時間等を正確敒知り得ないので逆行 性条件付けとなるのを極力さけ，しかもできるだけ 0.5 sec に近ずけるように心掛けた。電気ショックの強度決 定は電極淁着後に固有電気抵抗を湘定し，それにより一 応の強度を決定，強化過程に入ってから適宜調節した。

\section{第 2 項 実験成續並びに総括}

反応（条件皮盛電気反射）の有無の決定の規準恃第 1 編と同様とした。条件形成の決定は G（嗅刺激だけ） で上記規準の反応が 2 回以上見られた場合とし，条件形 成までの刺激回数は反応の見られた $\mathrm{G}$ の前の $\mathrm{G}+\mathrm{S}$ ま での回数と見なし，これをるつて現わした。

(1) 強化の劵戨

30 例飞就いてストロベリ一原液に上る强化を行つた 結果は第 7 表に示す通りで，条件形成されたものは73.3 \%であり，条件形成までの回数の分布は第 8 図炕見られ るごとくで大部分が 16 回までに条件形成が成立してい る.

不能 8 例 $(26.7 \%)$ 中6 例は電気ショックによつても 皮風電気反射の起らないもので残り2 例が $\mathrm{G}+\mathrm{S}$ では 反応が現れるが 条件形成のできなかつたもので32 回以 上の強化を施行することによりあるい、条件形成ができ たかもしれないと考觉られる。 
第 7 表

\begin{tabular}{|c|c|c|c|c|c|c|c|c|c|}
\hline & 证 & 例 & \begin{tabular}{|l} 
条件形会 \\
成ま \\
o回数
\end{tabular} & $\begin{array}{l}\text { 消去ま } \\
\text { での回 } \\
\text { 数 }\end{array}$ & & 定 & 例 & \begin{tabular}{|l}
$\mid$ 条件形 \\
成まで \\
の回数
\end{tabular} & $\begin{array}{l}\text { 消去ま } \\
\text { での回 } \\
\text { 数 } \\
\end{array}$ \\
\hline I & 士 & 0 & 7 & 11 & 16 & 田 & 0 & 15 & 4 \\
\hline 2 & 哺 & 0 & 7 & 8 & 17 & 野 & 0 & 7 & 7 \\
\hline 3 & 舆 & 0 & 12 & 7 & 18 & $川 1$ & 0 & - & - \\
\hline 4 & 服 & 0 & - & - & 19 & 名 & 0 & 9 & 8 \\
\hline 5 & 松 & 0 & 9 & 8 & 20 & 中 & 0 & - & 一 \\
\hline 6 & 嚓 & 0 & - & - & 21 & 0 & 典 & 15 & 5 \\
\hline 7 & 鼣 & 0 & - & - & 22 & 离 & 0 & $12^{* \prime \prime}$ & 6 \\
\hline 8 & 宗 & 0 & 4 & 10 & 23 & 证 & 0 & 7 & 11 \\
\hline 9 & 近 & 0 & 12 & 9 & 24 & 0 & 持 & 9 & 10 \\
\hline 10 & 轁 & 0 & 7 & 11 & 25 & 内 & 0 & 9 & 7 \\
\hline 11 & 生 & 0 & 12 & 8 & 26 & 0 & 井 & 23 & 6 \\
\hline 12 & 上 & 0 & 4 & 7 & 27 & - & 0 & 7 & 11 \\
\hline 13 & 江 & 0 & 12 & 10 & 28 & 谷 & 0 & - & 一 \\
\hline 14 & 太 & $\bigcirc$ & - & - & 29 & 吉 & 0 & - & - \\
\hline 15 & 大 & 0 & 20 & 5 & 30 & 14 & 0 & 9 & 7 \\
\hline
\end{tabular}
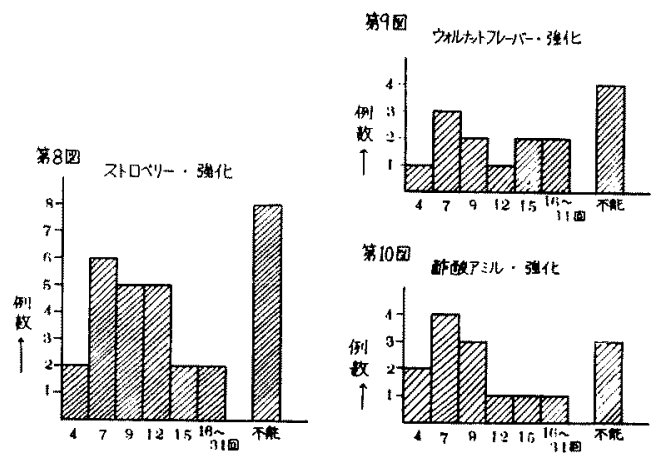

(2) 消去の舆鈤

强化の笑験において 采件形成のできたもの22 例に対 し続いて消去罗験を施行した。嗅刺湤は強化と同様ス卜 ロベリーエッセンス原液を使用し間隔時間は第 6 表に示 したものと同じにした（すなわら第6表中の GS は G となる).

反応が連緦して 3 回現れなくなつた時，消去されたも のと判定した。その結果は第7表に示す通りで最す早く 消去されたものは4回で消去されて沶り，又，11回以 上のbのが 4 例あり，艺の中には20回以上の\&のが 2 例あつた、又，消去までの回数は7回から10回までの

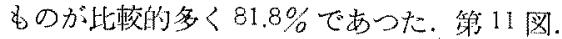

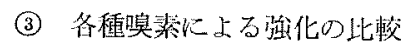

(1) の㝵留ではストロベリー原渡による強化を行つた
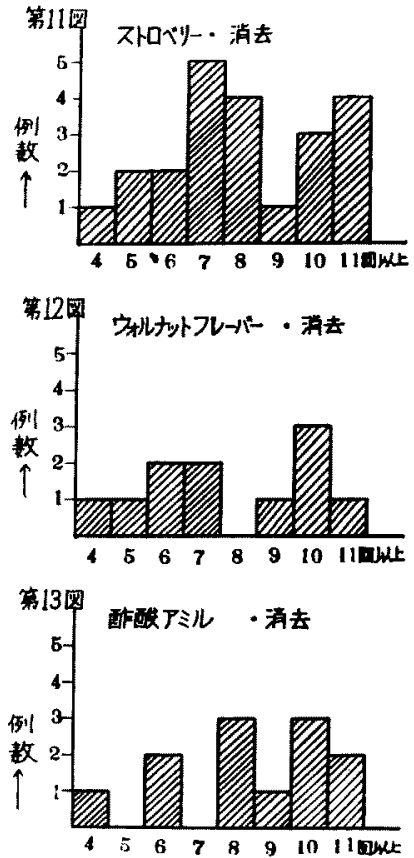

が，他の種類の県素による条件形成率を検べるために， 快莫であるストロベリーエッセンスに対し不快貝である ウオルナットフレーハーを, 又, 刺激峊としては醋㖶了 ルミを，いずれも原液で用い強化を行つた，実験方法は (1) と全く同様で消去過程も同時に実験した。

央験成續は第９図，第10 図に示寸通りで，(1)の串験 で行つたストロベリ一原液による強化との比較ではその 形成率にはとんど差が認められず（第8表），わずかに 刺激奥である醋酸アルミが高率を示した。，消去までの回 数もストロベリーエツセンス原液によるるのと比較して 特に差は認められなからた（第 12,13図).

第 8 表 各種搝素原液による強化率の比較

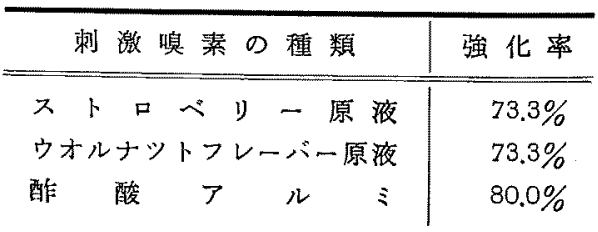

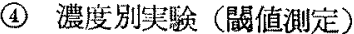

先の実験では嗅素原液による強化を行つたが，稀釈嗅 秦による強化の方が閶值測定には有利であるので被検者

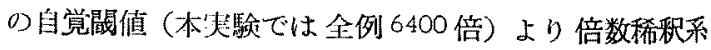
列で 2 番及び 4 番高濃度（1600 倍，400 倍）を使用し， 
同一人に対し日を異にして強化過程を行つた。結果は第 9 表の通りで 1600 倍でも400倍でも特に差異を認めず， 又、形成率る73.3\%で原液によるものと同様であつた。 以上の実験で強化成立した被検者には続いて閏倠測定を

第 9 表 稀积唤素による強化

\begin{tabular}{|c|c|c|c|c|}
\hline & 症 & 例 & $\mathrm{ST}_{400 x}$ & $\mathrm{ST}_{1600 \times}$ \\
\hline 1 & 内 & 0 & 4 & 7 \\
\hline 2 & 吉 & 0 & 15 & 12 \\
\hline 3 & 秋 & 0 & - & - \\
\hline 4 & 上 & 0 & 7 & 7 \\
\hline 5 & - & 0 & - & - \\
\hline 6 & 稲 & 0 & 7 & 9. \\
\hline 7 & 市 & 0 & 12 & 15 \\
\hline 8 & 加 & 0 & 7 & 15 \\
\hline 9 & $太$ & 0 & 7 & 4 \\
\hline 10 & 大 & 0 & 15 & 15 \\
\hline 11 & 平 & 0 & - & - \\
\hline 12 & 中 & 0 & 12 & 12 \\
\hline 13 & 宮 & 0 & 9 & 12 \\
\hline 14 & 重 & 0 & - & - \\
\hline 15 & 服 & 0 & 9 & 7 \\
\hline 形 & 成 & 率 & $73.3 \%$ & $73.3 \%$ \\
\hline
\end{tabular}

第 10 表 闒 值 測 定

\begin{tabular}{|c|c|c|c|c|c|c|}
\hline & 症 & 例 & $\mathrm{ST}_{6400 \times}$ & $\mathrm{ST}_{6400 \times}$ & $\mid \begin{array}{l}S T \\
1600 \times\end{array}$ & ST \\
\hline 1 & 内 & 0 & - & - & $H$ & $H$ \\
\hline 2 & 吉 & 0 & - & - & + & + \\
\hline 3 & 秋 & 0 & $H$ & $H$ & & \\
\hline 4 & 上 & 0 & - & $H$ & & \\
\hline 6 & 稻 & 0 & + & - & $\frac{+}{(6400 x)}$ & \\
\hline 7 & 市 & 0 & $H$ & $H$ & & \\
\hline 9 & 太 & 0 & $H$ & H & & \\
\hline 10 & 大 & 0 & - & - & + & + \\
\hline 12 & 中 & 0 & + & $H$ & & \\
\hline 13 & 宮 & 0 & $H$ & + & & \\
\hline 15 & 服 & 0 & - & + & $\begin{array}{c}+ \\
(6400 x)\end{array}$ & \\
\hline
\end{tabular}

第 11 表 自営闘値との関係

\begin{tabular}{l|r|r}
\hline $6400 \times$ で自覚閏值と一致したもの & 8 例 & $72.7 \%$ \\
$1600 \times$ ×゙反応の見られたもの & 3 例 & $27.3 \%$
\end{tabular}

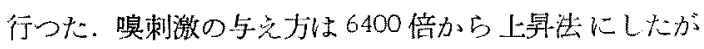

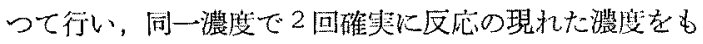
つて闒値とした。この結果は第10靑に示寸通りであり，

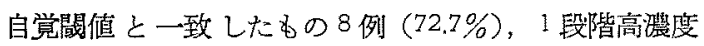
（1600 倍）で反応を示したもの3 例 (27.3\%)（第11表） で自覚閔值との差が 2 段階以上であつたものは 1 例も見 られなかつた。

\section{第 3 章 病 的者}

第 1 項 実験材料並びに买験方法

被検者：唄覚障書を主訴として当科火来院し，稀釈試

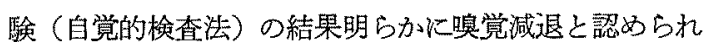

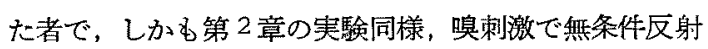
が成立する例は除外し，15 例に就いて実験を行つた。 特にこの中には第 1 編第 3 章の事験に㧅いて器反応を示 した4例が会まれている。

嗅覚脱失者は他に 5 例だけ行つた。

実験方法は条件形成に使用した嗅素濃度以外は第 2 章 (4) の実験と同様とし, 刺激嗅素濃度の決定は自覚閶值 の1/16 倍（倍数稀釈䊺で 4 番高濃度）を使用した。 脱失者はストロペリ一原液を用いて強化を試みた。

第 2 項 実験成績並びに総括

条件形成率は脱失者を対照としたものをの艺くと73.3 \%で正常者の場合と同率であり，第1 編で無反応であつ た者に対する強化では 2 例に拈いて条件形成ができた。

脱失者は全例全く条件形成が見られなからた。闒值测 定では第 12 表に示すことくで自覚䦪值と一致したもの 7 例 $(63.7 \%) ， 1$ 段階高濃度で反応を示したもの4 例 (36.3\%) で，それ以上自覚间值との差を示したものは 全く見られなかつた。

第 12 表

\begin{tabular}{|c|c|c|c|c|c|c|c|}
\hline 症例 & 氏 & 名 & 年令 & $\begin{array}{cc}\text { 䚁 } & \text { 稂 } \\
\text { 値 } \\
\end{array}$ & 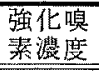 & $\begin{array}{l}\text { 他 撹 } \\
\text { 閶 } \\
\end{array}$ & $\begin{array}{l}\text { 自覚閂值 } \\
\text { 乞 の善 }\end{array}$ \\
\hline 1 & 高 & 0 & 21 & 100 & 原液 & 100 & 一 致 \\
\hline 2 & 圤 & 0 & 20 & 100 & 原液 & 100 & - \\
\hline 3 & 上 & 0 & 25 & 1600 & 100 & 1600 & 一 \\
\hline 4 & 吉 & 0 & 36 & 25 & 原液 & 原液 & 1 段階 \\
\hline 5 & 大 & 0 & 30 & 400 & 25 & 400 & 一 致 \\
\hline 6 & 武 & 0 & 28 & 400 & 25 & 100 & 1 階段 \\
\hline 7 & 0 & 島 & 28 & 400 & 25 & 100 & 1 階段 \\
\hline 8 & 土 & 0 & 45 & 25 & 原液 & 25 & 一 致 \\
\hline 9 & 中 & 0 & 37 & 100 & 原液 & 100 & - \\
\hline 10 & 内 & 0 & 41 & 400 & 25 & 100 & 1 階段 \\
\hline 11 & 田 & 0 & 17 & 400 & 25 & 400 & 一 致 \\
\hline
\end{tabular}




\section{第 4 章 考按}

条件反射を応用した他覚的娭查法任耳奥利領域では特 に聴力の他覚的检査法に関して多くの研究がなさ机て和 り，その大部分が本法と同しく笪気ショツクによつて誘 発される皮膚電気反射を哭条件反射系とするもので，政 にGSR 法と云えばこの方法を指寸程である。しかる に，いまた聴力検查法に扣いても瑤床的に使用される段 階には至つていない。

今日末で発表されてきた多くの他覚的検査法（嘼力， 鄓覚）は，そのほとんどが感覚刺激に対する非特異性の 反応を利用したものであり，本法の場合も知張りその通 りである.しかし臨床的に簡単に行なえる方法として は，それ以外に適当な方法の存在しない現状ではこのよ らな方法を十分に検討し，詐病者，その他の診断に役立 てるよらにする事が必要である。

1916 年 Watson, J. B. が条件皮簢電気反射について の研究を発表以来，これに関する論交は多数見られるよ らになつたが，喚刺激を条件刺激とするものは1958年 新美によつて報告された，紧刺激による人間の条件皮獻 電気反射の形成の可能性並びに汎化，分化に就いての論 文が見られるのみであり，他覚的嗅覚検查法に応用した あのは現在迄に全く見られないこれは嗅覚に関する研 究が種々の困難な面を持つているために見るべき進步が なからたこと，㖵刺激が皮鹰電気反射に対し，容易に無 条件刺激として作用すること，更に具体的に喚刺激筫荷 の方法的な困難性が存在する事等が主な理由であるう。

私は今回, 他覚的検查法兄の応用を主なる目的として 次にのべるよらな諸点については詳細に検討した．

先づ，無条件刺激となり得るものは種々存在するが， その中，電気ショックが強度の調節，刺激時間の決定等 全ての点で非常に有利であるのでこれを使用した，只， 刺激強度の決定には注意が必要であり，新美の論文に見 られる Psoude-Conditioned-Reflex の出現をきたさな いために強度決定段階を省略し，固有電気抵抗を参考に して一応の強度を決め強化過程に入つてから適宜調節し た. その強度は not painful but unpleasant と云われ ているが，これも個人善がはなはたしく，その表現も各 人各様であるので，この点を見い出すのは簡単ではな W.

条件刺激と無条件刺激との間隔は所謂延滞的条件形成 法より，同時的形成法の方が形成率が良いのであるが， 聴力㭘查の場合之違がつて暞刺激では逆行性条件付とな らないよらに非常な注意をはらわなくては，かえつて形

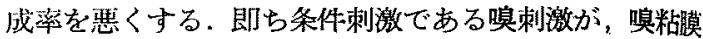
亚びに傻中枢に達した特期を正確に知り得ず，吸気の始 まつた但後をもつて嗅感の有つたものと認めざるを得 ず,これより $0.5 \mathrm{sec}$ 遅れて電気ショックを与觉るのが

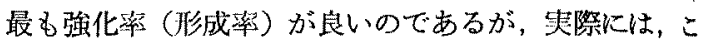
の点で正確であるのは困難であるので，逆行性条件付け

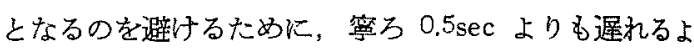
らにしたのが多い。

強化法のプログラムは，夹験方法でのべた通りで50\% 強化法により行つた，全部強化より，部分強化の方が消 去に刘して抵抗があり，閵值測定のためには，この方が 有利である。しかも50\%強化法であ数試行乃至十数誠 行で条件形成され，部分強化のため $\mathrm{G}$ のみの時に条件 形成されたか否かが判定できるので，本法には好都合で ある．又，十数試行以内に条件形成された事は試験開始 上り20分以内に条件形成された事であつて 条件唾液反 射などのよ5に条件形成までに時日を要するのに比較し その点でも本法は有利である。

条件皮鹰電気反射の反応は第 1 編と全く同じ形で現れ てくるもので，それが条件皮臂電気反射によるものか単 に瞁刺激によつて起つた皮膚電気反射であるかは反心曲 線だけでは区別がつかないが，部分強化法によつて最初 Gのみでは反応が現れず $G+S$ の後の $G$ に反応の現 れた状況によつて判定を下寸事ができるわけである。

刺激喚素は，まづストロペリーエッセンス原液を使用 し，嗅刺激による条件皮膚電気反射の形成を夷証し，次 に快臭, 不快臭, 刺激臭による形成率の比較を行つた。 不快臭及び刺激奥の方が快臭よりる形成率が高いと予想 したが，垁験成績からこの 3 者間に極めて僅少の差異し か認められずここの結果いかなる嗅素を使用してる，形 成率には大差がないるのと推考する，又，形成率が第! 編と比較してやや良かつた事は，第1編の方法上りは複 雑ではあるが有用な方法であると云劣る、特に第 1 編の 方法で, 全く反応の現れなかつた者でも, 本法によつて 条件付できた事は看過できない点である。

次に閾值測定にあたり，原液䝷素による強化より稀积 嗅素に上万強化の方が順庆（疲労）の発現し難い点から 有利であるので, 稀釈噚素による強化る原液による強化 と同じ形成率を示すならばそれを利用すべきであり，そ

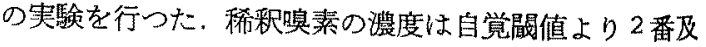
び 4 番高濃度のものを使用した。聴力揄査においてい閔 值上 30〜 40 db で強化を行つたと報告 (鈴木等) がある

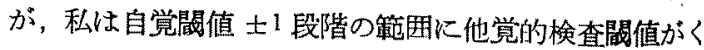


ると想定した結果，前記濃度のものを使用しれ。形成率 は原夜 400 倍, 1600 倍間に 差は認められず，閔值測定 には稀釈嗅素を使用ずる事とした。

間值測定にあたり次に問題となるのは消去であり，あ まり簡単に消去されてしまつたのでは閾值測定は不可能 である。各種原液それぞれについて行つた消去の結果は 前述の通りで，最も早く消去されたものでも 4 回であり 大部分は 7〜8 回以上で, 上昇法にて閶值測定を行なえ ば特に問題とはならない，稀积喚素によつて強化された ものの消去に就いても，実際に䦪值測定を行つた結果か ら見て，特に早いと思われるものはなかった。

䦪值測定の結果は第 11 表の通りで, 自営閾值 との差 から見て，第 1 編の場合よりかずかではあるが好成績で あり，聴力検查(鉿木篤郎)と活济同じ結果を得ている。

次に病的者を対象としたものについて 2，3 の考察を 加えると，まず刺激喚素澧度の決定であるが，自覚䦔值 が不明（あるいは測定不能）の場合には正常者に使用し た400倍で強化を行い，条件形成できなかつた場合には 洀次高濃度のるのを使用する方法, あるいは原液で強化 を行い，それによつて一応他党的閖值を測定し，その他 覚的闆值から強化濃度を決定し，あらためて闒值を測定 すると云う2 段階に分けた方法（この方法によれば先に のペた順応 (疲労) の問題から起る榆查成績の不正確が 除かれる) が考劣られる。

又，病的者の場合の条件形成率及び測定閾値の一致度 が，正常者群のそれと比較して大差なからた事から，本 法の検查法の有用性が認められる。

なお，脱失者に就いては，本法では条件刺激として使 用する嗅刺激を，全く感する事のできない脱失者にとつ て，条件形成が成立しなからたのは当然であると考え る、又，被検者は全く臭いはないと云っているにもか力 わらず，本法で明らか炕条件形成が成立したとするなら ば，それは多少なりとす莫つていたと考劣るべきで，こ の事実は詐病検查に利用できる.

以上総括すると，いかなる摬素を用いても，強化率に は大差はないが，逆行性条作付けとならない上らに注意 が必要であり，閔値測定にあつてはできるたけ低洤度の 瑱素による強化が良く，そのために強化率が悪くなるこ とはない，しかして上戒法によれば，特に消去を問題と

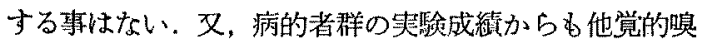
覚検植法として本法が有利な方法であると云える。

\section{第5章 結語}

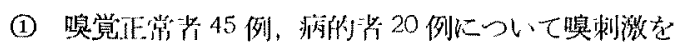

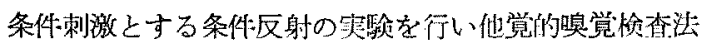
克の応用を検討した。

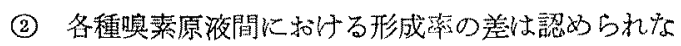
からた，又，稀鄱嗅素に上る強化も原液による強化と同

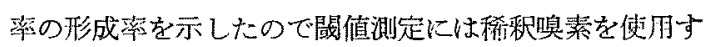
る事とした。

(3) 消去までの回数が閾值泪定に不便をきたすほど少 ないものはなからた。

(4) 第 1 編で筧反応であつた者も本法で反応（条件形 成できたもの）を示した例があつた。

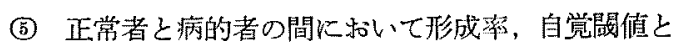
の差に有意の差を認めなかつた。

(6) 脱失者は全例，条件形成ができなからた。

(7) 第 1 編と同様不能例は比較的少なからた. 本法む 前法 (第 1 編) と並儿で他覚的唤覚㛟查法に応用すべき であり，特に前法にて無反応であつた者に対しては更に 本法を施行すべきである。

\section{參考文献}

1) Albrecht, $W$ : Die Trennung der nicht Organischen von der Organischen Hörstörung mit Hilfe des Psychogalvanisches Reflex, Arch. Ohrenusw. HLK. 101,1 (1918), 2) Avakyan, P. V.: The use of conditioned blinking reflexes for the investigation of the activity of the auditory analysor in man (abstr.), Exp. med. (sect. XI) II, 220(1958) 3) Berinoff, $S$ : Eine neue Metho der Klinischen Anwendung auropalpebralen Reflexes (Bechterew), Mschr. Ohrenhlk. 52, 423 (1918) 4) Bijtel, J. \& van Iterson, C. J. A.: Recherches sur le réflexe psychogalvanique, en partculier comme réaction aux excitations olfactives, Arch. néerl. physiol. 10, 447-448 (Cited by Landis, C. \& Be Wick, H.N.)

5) Bordley, J. E. and Hardy, W. G.: A study in objective audiometry with the use of a psychgalvanometryic response, Ann. Otol. 58, 751. (1949)

6) Bordley, J.E. and Haskins, H. L.: The role of the cerebrum in hearing, Ann. Otol. 64, 370 (1955) 7) Campbell, R. K.: Some difficulties in conditioning galvanic skin responses, Psychol. Bull. 33, 618 (1936) 8) Campbell, A. A. and Hilgard, E. R.: Individual differenses in case of conditioning, J. exp. Psychol. 19, 561 (1936) 9) Catlin, F. I.: Stimulators for psychogalvanic testing with special 
reference to clinical audometry, : Acta oto-laryng. 48, 374 (1957) 10) Coombs, C.H.: Adaptation of galvanic response to auditory stimuli, J. exp. Psychol. 22, 244 (1938) 11) Demes, P. and Neame, J.H.: Psychogalvanic audiometry, J. Laryng. 73, 690 (1959) 12) Freeman, G. L.: The galvanic dhenomenonand conditioned responses, J. gener. Psychol. 3, 529 (1930) 13) 藤森: 生理学講医, 精神電流現象, 中山墨怎, 65页. 14) 福息: 幼

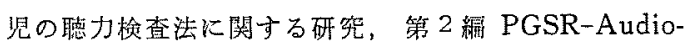
metry, 日耳鬼, 63 巻8号, 1847 頁. 15) Goldstein, R., Ludwig, H. and Naunton, R.F.: Difficulty in conditioning galvanic skin responses: Its possible significance in clinical audiometry. Acta. oto-laryng. 44, 67 (1954) 16) 後藤: 人体の電気現象とそ の応用，永非畫店，(1957) 17) Grant, D.A. and Schneider, D. E: Intensity of the conditioned stimulus and strength of conditioning. II, The conditioned galvanic skin response to an auditory stimulus, J. exp. Psychol. 39, 35 (1949) 18) Hilgard, E. R. and Campbell, A. A.: The course of acquisition and retention of conditioned eyelid responses in man, J. exp. Psychol. 19, 227 (1936) 19) Hovland, C.: The generalization of conditiond responses. IV. The effect of varying amounts of reinforcement upon the degree of conditioned responses, J. exp. Psychol. 21, 261 (1937) 20) Hovland, C.:

The generalization of conditioned responses. I. The sensory generalization of conditoned responses with varying frequencies of tone, J. gener. Psychol. 17, 125 (1937) 21) Hovland, C.: The generalization of condition responses. II. The sensory generalization of conditioned responses with varying intensities of tone, J. genet. Psychol. 51, 279 (1937)

22) Hovland, C.: The generalization of conditioned responses. III. Extinction, spontaneous recovery, and disinhibition of conditioned and of generalized responses, J. exp. Psychol. 21, 47 (1937)

市原：嗅賞の臨床，金原出版 (1963)

Knapp, P. H. and Gold, B.H.: The galvanic skin response and diagnosis of hearing disorders, Psychosomatic Med. 12, 6 (1950) 25) Landis, C. and Dewick, $H_{i} N_{i i}$ The electrical phenomena of the skin, Psychol. Bull. 26, 64 (1929) 26) Landis, G. and Hunt, W. A.. The conscious correlation of the galvanic response, J. exp. Psychol. 18, 506 (1935) 27) Laskiewicz, A.. Clinical considerations on the aural reflexes of Bechtrew and Kisch, Acta oto-laryng. 45, 355 (1955) 28) Lehrhoff, I. and Hills, B.: An experimental study of auditory threshold acuity in children with cerebral palsy by P.G.S.R. and other techni. ques, Ann. Otol. 67,643 (1958) 29) Michels, $M$. W. and Randt, C.T.: Galvanic skin response in the differential diagnosis of deafness, Arch. OtoLaryng. 45, 302 (1947) 30) 操担道, 他: 医学工 レクトロニクス, 南山堂 (1956) 31) Misbach, L. $E$.: Effect of pitch of tone stimul upon body resistance and cardiovascular phenomena, J. exp. Psychol. 15,167 (1932) 32) 本川: “電気生理学, 岩 波全書 (1957) 33) Neet, C.C.: A comparison of verbal, manual and conditioned response methods in the determination of auditory intensity thresholds, J. exp. Psychol. 19, 401 (1936) 34) 䉼 美：嗅敩刺激を条件刺激とした人間の条件皮有電気反 射 (第 I 報), 形成の可能性の実証, 歯科学報, 58 巻, 11 号 (1958) 35) Pavlov, I. P.: 条件反射学, 三 省堂 (1937) 36) Richter, C. P.: Physiological factors involved in the electrical resistance of the skin, Amer. J. Physiol. 88, 596 (1929) 37) 下 平：音櫘刺激による無条件皮咶反応とその聴力剆定へ の応用，日耳鼻，65巻，9号，1066頁 (1962) 38) Strauss, H., Landis, C, and Hunt, W. A.: Acoustic motor reactions especially the cochleopalpebral reflex, Arch. Otolaryng. 28,941 (1938) 39) 鈴 木(篤), 他: 他覚的聴力湘定、日耳鬼第61回総会宿题 報告（1960）40）問田：新生理学 (上巻) 動物的 機能編, 医学甾院 (1960) 41) Van Iterson, C.J. A.: Psychic-galvanic-reflex-phenomenon in ear examination, Acta Oto-Laryng. 2. 174 (1921) 42) W. Waemann,: Geruchssin, S. 39 H. N. O. HLK. Bd 1 (1964) 43) Wotzilka, G.: Eine neue Art von Hörprüfung bei hochgradiger Schwerhörigkeit und Taubheit, Mschr. Ohrenhk. 57, 880 (1923) 44) 山田: Psychgalvanic Skin Responses Kよる他 覚的聴力梌查法について, 日耳耳, 63 巻, 6 号 (1960).

終稿に当り恩師山本教授の御指導並びに御校閣に 深謝すると共に, 䅂始卸教導を戴いた市原助教授に 感謝する。

本碖文の要旨は第65回日本耳奥咽喉科学会総会に おいて発表した。

（原稿到着 $=$ 昭和 39.8 .24 日） 